\title{
Clinical Presentation, Complication and Outcome of Black Stone (Paraphenylene Diamine) Poisoning.
}

Hakim Ali Abro, Sultan Ahmed Chandio, Azizullah Jalbani, Sheeraz Ali Buriro, Aafia Saeed

1. Dr. Hakim Ali Abro

Professor, Chandka Medical College

2. Dr. Sultan Ahmed Chandio

Assistant Professor, Chandka Medical College

3. Dr. Azizullah Jalbani

Professor, Chandka Medical College

4. Dr. Sheeraz Ali Buriro

Senior Registrar, Chandka Medical College

5. Dr. Aafia Saeed

Postgraduate, Chandka Medical College

6. Dr. Faizan Shaukat

Postgraduate, Jinnah Post Graduate Medical Center

\section{$\underline{\text { Abstract }}$}

\section{Introduction}

In recent time, developing countries of South Asia and Africa have seen significant increase in ingestion of Para-Phenylene Diamine (PPD), locally known as Kala Pathar, either accidental or for suicide. Through this study, we aim to study the clinical presentations and outcomes among patients who have ingested PPD.

\section{Method}


medRxiv preprint doi: https://doi.org/10.1101/2020.10.24.20218800; this version posted October 27, 2020. The copyright holder for this preprint (which was not certified by peer review) is the author/funder, who has granted medRxiv a license to display the preprint in perpetuity. It is made available under a CC-BY-NC 4.0 International license .

This retrospective case series study was conducted in a tertiary care hospital of Pakistan, from April 2013 to August 2017. Data of patients of PPD poisoning was archived from the hospital's medical records. Around 174 consecutive cases were included in the study. Patients were evaluated based on self-administrated proforma.

\section{Result}

Out of 174 cases of PPD poisoning that were identified, 57(32.8\%) were males and 117(67.2\%) were females. The mean age \pm SD (range) of the patients was $24.16 \pm 9$ (10 to 70) years. Approximately 170 (97.8\%) patients used PPD for suicidal intention. The most common presentation was facial swelling which was present in 144(82.8\%) patients followed by dysphagia in 143(82.2\%) patients. Complications include metabolic acidosis in 50 (28.7\%) patients and aspiration pneumonia in $36(20.7 \%)$ patients. A total of 101 (58\%) improved, while others were either referred or left against medical advice (LAMA).

\section{Conclusion}

Increasing incidence of ingestion of PPD for suicide warrants the regulatory authorities to restrict the use of PPD in hair dyes and implement strict measures to educate masses and curtail the easy access of such poisonous substances among common people.

\section{Introduction:}

Globally, around one million deaths occur every year due to self-murder and in last half century the trend of suicide is escalated by $60 \%$ [1,2]. Different methods of committing self-harm are being practiced in different societies and many majorities of the people choose suicide for ending their life. Thus, currently numerous health care facilities are facing substantial number of poisoning cases in their emergencies [3]. Different trends of committing suicide are prevailing around the universe and mostly choice depends upon the social status as pesticides are commonly ingested in eastern and lower socio-economic class 
medRxiv preprint doi: https://doi.org/10.1101/2020.10.24.20218800; this version posted October 27, 2020. The copyright holder for this preprint (which was not certified by peer review) is the author/funder, who has granted medRxiv a license to display the preprint in perpetuity. It is made available under a CC-BY-NC 4.0 International license .

while in high socio-economic and influential societies, opiates and tranquillizers are used for this purpose $[4,5]$. South Asia and Africa are witnessing a increase number of people committing or attempting suicide with Paraphenylene diamine (PPD) which is responsible for enormous number of the deaths in these regions [6-8].

PPD is an organic by product of aniline dye with formula of $\mathrm{C}_{6} \mathrm{H}_{4}\left(\mathrm{NH}_{2}\right)_{2}$ and when oxidized in air, its color changes into black from white [9]. Principally, it enhances the dyeing process and is an ingredient of many hair color products currently available in market. Historically, PPD was mixed with henna for coloring hair and when ingested, it can prove to be lethal [10]. In developing countries, common man has easy access to get PPD from market for suicidal intention with no check and balance on its trade [11]. PPD is active constituent of Kala Pathar (Meaning Black Stone in Urdu) and when taken orally or used locally, it has harmful effects [10]. The active components of kala pathar includes 4\% PPD, resorcinol, propylene glycol, ethylene-diamine-tetraacetic acid (EDTA), sodium, liquid paraffin, cetostearyl alcohol, sodium lauryl sulphate, herbal extracts, preservatives, and perfumes [12]. Out of these, few have notorious fatal effects while poisonous profile of other substances is still in question. PPD principally produces its damaging effects on all the major organs of body like kidneys, liver, heart, lungs, muscles, and mucous membrane. Individuals affected with PPD poisoning rapidly develop edema of oral cavity and upper respiratory tract by producing local effects followed by rhabdomyolysis and acute kidney insult due to precipitation of its toxic breakdown products in renal tubules [13, 14]. Some of the studies have shown that persons using commercially available hair color have increased likehood to develop multiple myeloma, non-Hodgkin's Lymphoma, acute leukemia, and bladder cancer [15].

Currently, there is limited data available on this poisoning as it has emerged as a new trend in our local hospitals. So, the rationale of this study is to evaluate the clinical presentation and outcome of the PPD poisoning in our part so that effective preventive and treatment strategies can be implemented at the onset which would certainly decrease the morbidity and mortality associated with this deadly poisoning. This study can lay down a base for local administrative authorities to consider formulating a law for strict handling of the PPD poisoning at local level and for education of the population.

\section{Material and Methods:}


medRxiv preprint doi: https://doi.org/10.1101/2020.10.24.20218800; this version posted October 27, 2020. The copyright holder for this preprint (which was not certified by peer review) is the author/funder, who has granted medRxiv a license to display the preprint in perpetuity. It is made available under a CC-BY-NC 4.0 International license .

This retrospective case series study was conducted at the medical intensive care unit of Medical Unit-I of Chandka Medical College Hospital, Pakistan. All the PPD poisoning patients with both gender and more than 10 years age admitted to medical ICU were included. The diagnosis of PPD poisoning was based on clinical findings and information taken from the patient's family and friends. Patients with history of liver, cardiac and renal disease were excluded from study.

After approval by ethical review committee of the hospital, patient's data was retrieved from their medical record files. A pro-forma was used to collect data including demographic features (age, sex, marital status, socio economic status), clinical features including examination findings (especially cervico-facial edema, dysphagia, respiratory difficulty, syncope/coma, fits, color of urine, blood pressure, anemia, edema, oliguria), laboratory findings (complete blood count, liver function test, creatinine kinase [CK], lactate dehydrogenase [LDH], glucose, urea, creatinine, electrolytes and electrocardiogram [ECG]), mode of intoxication (accidental or suicide) and route of intoxication (gastrointestinal system, skin) was recorded. Hospitalization time after the ingestion, intent of ingestion (accidental or intentional) total hospital stays, amount of poison ingested, complications and final outcomes in the form of improvement, referral and death were also recorded.

Data was analyzed on computer using SPSS software version 19. The detailed sociodemographic data like age, gender, marital status and other clinical data like duration, route and intent of poisoning was recorded. The mean and standard deviation (SD) was calculated for age and duration of poisoning. Frequencies and percentages were calculated for gender, clinical presentation including examination findings, route, intent of poisoning and outcome in the form of improvement and discharge from hospital, referral and death was be calculated. Post stratification Chi square test was be used to see for significance and $\mathrm{p}$ value of $\leq 0.05$ meant null hypothesis is not applicable and there is a difference between variables.

\section{Results}

Total 174 consecutive cases with PPD poisoning were observed during the study period. Out of them 57(32.8\%) were males and 117(67.2\%) were females. The mean age \pm SD (range) of the patients was $24 \pm 9$ (10 to 70 ) years with range of minimum 10 years and maximum 70 years and 
medRxiv preprint doi: https://doi.org/10.1101/2020.10.24.20218800; this version posted October 27, 2020. The copyright holder for this preprint (which was not certified by peer review) is the author/funder, who has granted medRxiv a license to display the preprint in perpetuity. It is made available under a CC-BY-NC 4.0 International license .

majority of the patients $82(47.1 \%)$ were in the age group 21-30 years followed by $66(37.9 \%)$ patients were in the age group 21 to 30 years, 17(9.8\%) were seen in age group 31 to 40 years, $7(74.0 \%)$ were observed in the age group 41 to 50 years and only $1(0.6 \%)$ patient was seen tin the group 51 to 60 years or above $>60$ years.

Regarding the marital status 106 (60.9\%) were unmarried while 68 (39.1\%) were married. As far as socioeconomic status of the cases is concerned, 137 (78.7\%) belonged to poor background, 35 $(20.1 \%)$ were middle class cases and $2(1.1 \%)$ belonged to high class.

Regarding reasons of ingestion, suicidal intention was observed in 170 (97.8\%), in 2 (1.1\%) patients it was accidental and homicidal, respectively. All 174 patients ingested local made, black stone-based hair dye via oral route.

The time interval to reach hospital ranged from 1 to $24 \mathrm{~h}$ with a mean duration of $5.36 \pm 4.67$ hours. Out of 174 patients, 138 (79.3\%) were brought to hospital emergency less than 6 hours, $33(19.0 \%)$ patients were brought between 6 to 18 hours and only $3(1.7 \%)$ patients reached the hospital after more than 18 hours (table 1)

\begin{tabular}{|c|l|l|}
\hline Variable & Number & Percentage \\
\hline Mean Age \pm SD in years (Range) & \multicolumn{2}{|c|}{$24 \pm 9.0(10$ to 70 years) } \\
\hline Gender & 57 & $32.8 \%$ \\
\hline Male & 117 & $67.2 \%$ \\
\hline Female & & \\
\hline $\begin{array}{c}\text { gge Group } \\
10 \text { to 20 Years }\end{array}$ & 82 & $47.1 \%$ \\
\hline 21 to 30 Years & 66 & $37.9 \%$ \\
\hline 31 to 40 Years & 17 & $9.8 \%$ \\
\hline 41 to 50 Years & 07 & $4.0 \%$ \\
\hline 51 to 60 Years & 01 & $0.6 \%$ \\
\hline More than 60 Years & 01 & $0.6 \%$ \\
\hline Marital Status & & \\
\hline Married & & $39.1 \%$ \\
\hline Unmarried & 68 & $60.9 \%$ \\
\hline
\end{tabular}




\begin{tabular}{|c|l|l|}
\hline Socio Economic Status & & \\
\hline Lower Class & 137 & $78.7 \%$ \\
\hline Middle Class & 35 & $20.1 \%$ \\
\hline High Class & 02 & $1.1 \%$ \\
\hline $\begin{array}{c}\text { Reason of Taking Poison } \\
\text { Suicidal }\end{array}$ & 170 & $97.8 \%$ \\
\hline $\begin{array}{c}\text { Homicidal } \\
\text { Accidental }\end{array}$ & 02 & $1.1 \%$ \\
\hline Time of Arrival & 02 & $1.1 \%$ \\
\hline Less than 6 Hours & 138 & $79.3 \%$ \\
\hline 6 to 18 Hours & 33 & $19.0 \%$ \\
\hline More than 18 Hours & 03 & $1.7 \%$ \\
\hline
\end{tabular}

The clinical presentation of patients was proportionately associated with the amount and the type of dye consumed. Most common presentation was facial swelling which was present in $144(82.8 \%)$ patients and dysphagia was second most common symptom which was seen in $143(82.2 \%)$ patients. Respiratory difficulty was present in 142(81.6\%) patients. Other common presentations were tachycardia, pain and rigidity of limb, cola brown color urine, palpitation, decrease urine output, nasal twang of voice, oliguria, pre-syncope, chest Pain, anuria, nasal regurgitation, and convulsion. These patients had a history of immediate swallowing of large amount of hair dye and developed features suggestive of myocarditis (Table 2). 


\begin{tabular}{|l|l|l|}
\hline Symptoms & & \\
\hline Facial Swelling & 144 & $82.8 \%$ \\
\hline Dysphagia & 143 & $82.2 \%$ \\
\hline Respiratory Difficulty & 142 & $81.6 \%$ \\
\hline Tachycardia & 128 & $73.6 \%$ \\
\hline Pain and Rigidity of Limb & 124 & $71.3 \%$ \\
\hline Cola Brown Color Urine & 123 & $70.7 \%$ \\
\hline Palpitation & 89 & $51.1 \%$ \\
\hline Decrease Urine Output & 78 & $44.8 \%$ \\
\hline Nasal Twang of Voice & 51 & $29.3 \%$ \\
\hline Oliguria & 36 & $20.7 \%$ \\
\hline Pre-syncope & 33 & $19.0 \%$ \\
\hline Chest Pain & 30 & $17.2 \%$ \\
\hline Anuria & 29 & $16.7 \%$ \\
\hline Nasal Regurgitation & 20 & $11.5 \%$ \\
\hline Convulsion & 20 & $11.5 \%$ \\
\hline
\end{tabular}

With regards to clinical examination, out of 174 patients, mean temperature \pm standard deviation (SD) was $98.8 \pm 0.7$, mean pulse \pm SD was $110 \pm 28$, mean respiratory rate \pm SD was $26 \pm 07$, mean blood pressure (BP) systolic \pm SD was $131 \pm 27$ and mean BP diastolic \pm SD was $80.3 \pm 19$. Facial edema was seen in $144(82.8 \%)$ cases followed by dehydration in $88(50.6 \%)$ cases, cyanosis in 25(14.4\%), jaundice in 22(12.6\%) and anemia was seen in 9(5.2\%) cases (table 3). 


\begin{tabular}{|c|c|c|}
\hline Vitals & \multicolumn{2}{|c|}{ Mean \pm Standard Deviation } \\
\hline Temperature & \multicolumn{2}{|l|}{$98.8 \pm 0.7$} \\
\hline Pulse & \multicolumn{2}{|l|}{$110 \pm 28$} \\
\hline Respiratory Rate & \multicolumn{2}{|l|}{$26 \pm 07$} \\
\hline Blood Pressure Systolic & \multicolumn{2}{|l|}{$131 \pm 27$} \\
\hline Blood Pressure Diastolic & \multicolumn{2}{|l|}{$80.3 \pm 19$} \\
\hline Sub vitals & Number of patients & Percentage \\
\hline Facial Edema & 144 & $82.8 \%$ \\
\hline Dehydration & 88 & $50.6 \%$ \\
\hline Cyanosis & 25 & $14.4 \%$ \\
\hline Jaundice & 22 & $12.6 \%$ \\
\hline Anemia & 09 & $5.2 \%$ \\
\hline
\end{tabular}

Regarding laboratory investigations, the mean \pm standard deviation of complete blood count (CBC) such as hemoglobin (\%), total leukocyte count (TLC), serum platelet levels were $12.6 \pm 2.4,18376 \pm 12356$ and $287125 \pm 100303$ respectively. Mean random blood sugar level was 166.0 \pm 78.0 and LFTs (liver function tests) such as total bilirubin (mg/dL), Alanine Aminotranferase (U/L), Alkaline Phosphatase (U/L) levels were $0.8 \pm 0.5,144 \pm 166$, and $162 \pm 70$ respectively. Renal function was estimated as mean $\pm \mathrm{SD}$ of serum urea $(\mathrm{mg} / \mathrm{dL})$ and creatinine $(\mathrm{g} / \mathrm{dL})$ levels, which were $42.6 \pm 32$ and $1.3 \pm 1.0$. 
medRxiv preprint doi: https://doi.org/10.1101/2020.10.24.20218800; this version posted October 27, 2020. The copyright holder for this preprint (which was not certified by peer review) is the author/funder, who has granted medRxiv a license to display the preprint in perpetuity. It is made available under a CC-BY-NC 4.0 International license.

9

Creatine phosphokinase (CPK) levels were found to be increased, i.e. above 300 IU. Mean CPK $\pm \mathrm{SD}$ (range) was $73591 \pm 127371$ (3200 to 1055010). CPK levels gradually decline reaching normal levels within an average period of 10 days. Chest X-ray showed features of aspiration in $6(3.5 \%)$ patients and normal chest X-ray was seen in 149(85.6\%) patients. ECG abnormalities like sinus tachy-arrhythmias were observed in 14(8.0\%) patients and brady-arrhythmia in $9(5.2 \%)$ patients.

In this study, 11 of 174 patients $(6.3 \%)$ developed acute hepatitis within 6 hours of poison intake. Metabolic acidosis was evident in 50 of 174 cases (28.7\%). Around 36(20.7\%) of 174 patients with CPK levels more than 10,000 IU/L developed renal failure (elevation of serum creatinine) and required dialysis, while 36(20.7\%) patients developed aspiration pneumonia. Arrhythmia was seen in $30(17.2 \%)$ patients. Hypocalcaemia was observed in 12(6.9\%) patients. Only $1(0.6 \%)$ patient suffered from bleeding (table 4$)$. 


\begin{tabular}{|c|c|c|}
\hline Complete Blood Count (CBC) & \multicolumn{2}{|c|}{ Mean \pm Standard Deviation } \\
\hline $\mathrm{HB} \%$ & \multicolumn{2}{|l|}{$12.6 \pm 2.4$} \\
\hline Total Leukocyte Count & \multicolumn{2}{|c|}{$18376 \pm 12356$} \\
\hline Platelet Count & \multicolumn{2}{|c|}{$287125 \pm 100303$} \\
\hline \multicolumn{3}{|l|}{ Blood sugar (mg/dL) } \\
\hline Random Blood Sugar & \multicolumn{2}{|l|}{$166.0 \pm 78.0$} \\
\hline \multicolumn{3}{|l|}{ Liver Function Tests (LFTs) } \\
\hline Total Bilirubin (mg/dl) & \multicolumn{2}{|c|}{$0.8 \pm 0.5(02$ to 3.6$)$} \\
\hline ALT (U/L) & \multicolumn{2}{|c|}{$144 \pm 166(10$ to 1191$)$} \\
\hline Alkaline Phosphates (U/L) & \multicolumn{2}{|c|}{$162 \pm 70(170$ to 1325$)$} \\
\hline \multicolumn{3}{|l|}{ Renal function } \\
\hline Urea $(\mathrm{mg} / \mathrm{dl})$ & \multicolumn{2}{|c|}{70 to $235(42.6 \pm 32)$} \\
\hline Creatinine (mg/dl) & \multicolumn{2}{|c|}{0.3 to $8.3(1.3 \pm 1.0)$} \\
\hline Serum Creatine Phosokinase U/L & \multicolumn{2}{|c|}{3200 to $1055010(73591 \pm 127371$} \\
\hline Chest X-Ray & Number of patients & Percentage \\
\hline Findings of Aspiration & 06 & $3.5 \%$ \\
\hline Normal Chest X-ray & 149 & $85.6 \%$ \\
\hline Not done & 19 & $10.9 \%$ \\
\hline \multicolumn{3}{|l|}{ Electrocardiogram } \\
\hline Brady-arrhythmia & 09 & $5.2 \%$ \\
\hline Tachyarrhythmia & 14 & $8.0 \%$ \\
\hline
\end{tabular}


11

\begin{tabular}{|c|l|l|}
\hline Normal & 151 & $86.8 \%$ \\
\hline Hepatitis B Surface Antigen & & \\
\hline Positive & 6 & $3.4 \%$ \\
\hline Negative & 75 & $43.1 \%$ \\
\hline Not done & 93 & $53.4 \%$ \\
\hline Hepatitis C Antibodies & & \\
\hline Positive & 05 & $2.9 \%$ \\
\hline Negative & 76 & $43.7 \%$ \\
\hline Not done & 93 & $53.4 \%$ \\
\hline Complications & & \\
\hline Metabolic acidosis & 50 & $28.7 \%$ \\
\hline Aspiration Pneumonia & 36 & $20.7 \%$ \\
\hline Renal Failure & 36 & $20.7 \%$ \\
\hline Arrhythmias & 30 & $17.2 \%$ \\
\hline Hypocalcemia & 12 & $6.9 \%$ \\
\hline Bleeding & 01 & $0.6 \%$ \\
\hline
\end{tabular}

In our study, most of the patients i.e. 128(73.6\%) patients had duration of hospital stay less than 7 days, 37(21.2\%) patients had duration of hospital stay 7 to 14 days and 9(5.2\%) patients had hospital stay more than 14 days (Table 5).

\begin{tabular}{|c|l|l|}
\hline Duration of Hospital Stay & & \\
\hline Less than 7 days & 128 & $73.6 \%$ \\
\hline 7 to 14 days & 37 & $21.2 \%$ \\
\hline More than 14 days & 9 & $5.2 \%$ \\
\hline
\end{tabular}

Overall, mortality was noted in 52 (29.9\%); out of these, 44 patients had hospital stay less than 7 days, 4 patients had duration of hospital stay from 7 to 14 days and more than 14 days respectively. Around 101 (58.0\%) patients achieved complete clinical recovery. Remaining 21 patients were referred or left against medical advice (LAMA) (table 6). 


\section{Hospital Stay to Outcome}

\begin{tabular}{|l|l|l|l|l|l|}
\hline Character & Improved & Expired & Referred & Lama & Total \\
\hline Less than 7 days & $67(52.3 \%)$ & $44(34.3 \%)$ & $08(6.3 \%)$ & $09(7.1 \%)$ & $128(100 \%)$ \\
\hline 7 to 14 days & $30(81.0 \%)$ & $04(10.8 \%)$ & $02(5.5 \%)$ & $01(2.7 \%)$ & $37(100 \%)$ \\
\hline More than 14 days & $04(44.4 \%)$ & $04(44.4 \%)$ & $01(11.2 \%)$ & $0(0 \%)$ & $09(100 \%)$ \\
\hline Total & & & & & \\
\hline
\end{tabular}

\section{Discussion}

Kala Pathar (PPD) poisoning is emerging means of intentional self-harm with high mortality in Pakistan [16]. Easy availability, low cost, and harmful effects of this hair dye ingestion makes it a frequent choice for committing self-harm [16]. It is used to commit suicide or can be ingested accidentally. It can also be mixed in edibles with criminal intentions and given to innocent victims.

In the present study, a sample of 174 poisoned patients by PPD (hair dye) was studied. We found that majority of the patients $82(47.1 \%)$ were in the age group 21-30 years. Elgamel AA et al. [17] reported a peak incidence at 17-27 years, while Musa et al. [18] reported the peak incidence between 21 and 30 years. This may be due to stress which increases at this age. In comparison to study conducted by Sakuntala et al [19], who reported same observation in his study that prevalence was more in the age group of 21- 30 years with female preponderance of $80.64 \%$. According to Nisar Khan et al, young age-group (mean $22.08 \pm 6.42$ year) is the main sufferer of kala-pathar poisoning [20]. It is consistent with many other studies. Akbar et al [8] reported the mean age as 25.5 \pm 4.56 years, Chrispal et al [21] as 27.75 years, and Suliman et al [22] as 40 years. This finding is also in accordance with the WHO report that young age group is more vulnerable to have self-harm in the low- and middle-income countries [20]. 
medRxiv preprint doi: https://doi.org/10.1101/2020.10.24.20218800; this version posted October 27, 2020. The copyright holder for this preprint (which was not certified by peer review) is the author/funder, who has granted medRxiv a license to display the preprint in perpetuity. It is made available under a CC-BY-NC 4.0 International license .

13

Most patients in this study were young females who ingested the poison with the intent of suicide or self-harm. Elgamel AA et al. also found that that (80.5\%) were females and the $(19.5 \%)$ were males [17]. Nisar Khan et al. documented that the female gender was primarily affected by this poisoning with male to female ratio of 1:18 [20]. A study from Sudan by Suliman et al. reported male to female ratio as 1:4 [22]. A study from Hyderabad, India by Sakuntala et al. reported it in females $80.64 \%$ as compared to males $18.75 \%$ [19]. A study from Multan, Pakistan by Akbar et al also showed similar results [8]. All the five patients in their case-series were females [8]. The explanation for female preponderance could be the use of kala-pathar as a low cost and easily available hair dye. Besides this, females are more exposed to gender inequities and social pressures in the developing countries. In the present study, 106 (60.9\%) were unmarried, while $68(39.1 \%)$ were married. Nisar Khan et al. showed, 71.1\% patients were unmarried [20].

In our study, we found that suicidal intention was observed in 170 (97.8\%) patients, while in 2 (1.1\%) patients it was accidental and homicidal each. Similarly, Nisar Khan et al. in his study revealed a high proportion of PPD intoxication (94.74\%) based on suicidal intention as well, which favors the contribution of social factors toward this event [20]. This finding is also consistent with other studies i.e. Akbar et al [8] from Pakistan identified suicidal intention in $60 \%$ cases, and Suliman et al [22] from Sudan identified suicidal ideation in $84 \%$ cases. This shows that PPD as accidental intoxicant is not common in the developing world. Khaskheli MS et al. reported that the intent of poisoning was suicidal in $98.94 \%$ of his cases; however psychological evaluation was found to be normal in all these patients [23]. This indicated that most of suicidal attempts were impulsive precipitated by either scolding from parents, family quarrels or socioeconomic reasons [24]. In our study, all patients were exposed to hair dye (black stone) through oral route probably due to ease of administration.

In the current study, facial swelling edema was the most frequent which required emergency tracheostomy. Dysphagia (82.2\%), respiratory difficulty $(81.6 \%)$ and tachycardia $(73.6 \%)$ were among other common complaints. A prospective study by Jain et al, comprising of 1020 patients with hair dye poisoning in India, reported that the development of severe facial edema occurred in $73.03 \%$, dark urine in $53.82 \%$, and muscular pain in $47.05 \%$ patients [25]. Moreover, facial edema was the first symptom to develop as observed in other studies as well [21, 26]. Suliman et al. reported acute renal failure in $60 \%$ of their patients [22]. Shock was another important feature due to PPD poisoning which occurred in $18.5 \%$ patients in our series. 
medRxiv preprint doi: https://doi.org/10.1101/2020.10.24.20218800; this version posted October 27, 2020. The copyright holder for this preprint (which was not certified by peer review) is the author/funder, who has granted medRxiv a license to display the preprint in perpetuity. It is made available under a CC-BY-NC 4.0 International license.

14

The mean time of arrival at the hospital in the present study was $5.36 \pm 4.67$ hours. This is comparable to the mean arrival time of $8.9 \pm 10.9$ hours stated in a study in India [27]. Nisar Khan et al [20] showed the mean time to reach the hospital was 4.68 \pm 5.31 hours.

In this study, the overall mortality was noted in 52 (29.9\%) patients; out of these, 44 patients had hospital stay less than 7 days, 4 patients had duration of hospital stay from 7 to 14 days and more than 14 days respectively. Approximately 101 (58.0\%) patients achieved complete clinical recovery. It was comparable to Kallel et al. and Sakuntala et al [19, 26].

PPD poisoning is more pronounced among youngsters, illiterate and poor people of the developing countries especially in rural areas. The high rate of morbidity and mortality has raised health concerns associated with PPD poisoning. Intensive supportive care and appropriate interventions including tracheostomy is the mainstay of management. PPD containing hair dyes are a great hazard and have been banned in countries like Germany, France and Sweden. However, in Pakistan it is still commonly used due to easy availability and access in many parts and needs to be banned. 


\section{REFERENCES:}

1. WHO World Suicide Prevention Day 2008; WHO statement; 2008.

2. Kumar KS, Yesudas S. Hair Dye Poisoning and the Developing World. J Emerg Trauma Shock.. 2009; 2(2): 129 - 131. 10.4103/0974-2700.50749

3. Lee HL, Lin HJ, Yeh STY, Chi CH, Guo HR. Pre- sentation of patients of poisoning and predictor of poisoning-related fatality: findings form a hospital-based prospective study. $\begin{array}{lllll}\text { BMC } & \text { Public } & \text { health } & \text { 2008; }\end{array}$ https://bmcpublichealth.biomedcentral.com/articles/10.1186/1471-2458-8-7

4. Michel K, Ballinari P, Bille-Brahe U, et al. Methods used for para suicide: results of the WHO/EURO multicenter study on para suicide. Soc Psychiatry Psychiatr Epidemiol 2000; 35: 156-63. 10.1007/s001270050198

5. Gunnell D, Ho D, Murray V. Medical management of deliberate drug overdose: a neglected area for suicide prevention? Emerg Med J 2004; 21: 35-8. 10.1136/emj.2003.000935

6. Suliman SM, Homeida M, Aboval OI. Paraphenyl- ene diamine induced acute tubular necrosis following hair dye ingestion. Human Toxicol 1983; 2: 633-5. $\underline{10.1177 / 096032718300200408}$

7. Sampathkumar K, Sooraj YS, Mahaldar AR, Ajeshkumar RP, Muthiah R. Hair dye poisoning. An emerging threat. Indian J Crit Care Med 2007; 11: 212-4. 10.4103/09742700.50749

8. Akbar MA, Khaliq SA, Malik NA, Shahzad A, Tarin SM, Chaudhary GM. Kala pathar (paraphenylene diamine) intoxication; a study at Nishtar Hospital Multan. Nishter Med $\mathbf{J}$ 2010 2: $111-5$. https://scholar.google.com/scholar?q=intitle:Kala\%20Pathar\%20(Paraphenylene\%20diami n)\%20intoxication:\%20a\%20study\%20at\%20Nishtar\%20Hospital\%20Multan

9. Merck Index, 11th Edition, 7256.

10. Sakuntala P, Khan PM, Sudarsi B, Mohar S, Siddeswari R, Swaroop K. Clinical profile and complications of hair dye poisoning. Internat J Scientific Res Pub 2015; 5: 51-4. http://www.ijsrp.org/research-paper-0615/ijsrp-p4211.pdf 
medRxiv preprint doi: https://doi.org/10.1101/2020.10.24.20218800; this version posted October 27, 2020. The copyright holder for this preprint (which was not certified by peer review) is the author/funder, who has granted medRxiv a license to display the preprint in perpetuity. It is made available under a CC-BY-NC 4.0 International license .

16

11. Khuhro BA, Khaskheli MS, Sheikh AA. Paraphenylene diamine poisoning: our experience at PMC Hospital Nawabshah. Anaesth Pain Intens Care. 2012;16(3):243-46.

https://www.researchgate.net/publication/286805261_Paraphenylene_diamin e_poisoning_Our_experience_at_PMC_Hospital_Nawabshah

12. Nohynek GJ, Fautz RF, Benech-Kieffer, Toutain H .Toxicity and human health risk of hair dyes. Food and Chemical Toxicology 2004;42(4):517-543. 10.1016/j.fct.2003.11.003.

13. Prabhakaran ACJ. Paraphenylene diamine poi- soning. Indian J Pharmacol. 2012; 44: 423-4. 10.4103/0976-9668.101924

14. Ram R, Swarnalatha G, Prasad N, Dakshinamurty KV. Paraphenylenediamine ingestion. An uncom- mon cause of acute renal failure. Postgrad J Med 2007; 53: 181-2. DOI: $10.4103 / 0022-3859.33860$

15. Rollison, DE; Helzlsouer KJ, Pinney SM . Personal hair dye use and cancer: a systematic literature review and evaluation of exposure assessment in studies published since 1992.Journal of Toxicology and Environmental Health , Critical Reviews,2006; 9 (5): 413-39. 10.1080/10937400600681455

16. Ahmed Khan M, Akram S, Bin Usman Shah H. Epidemic Of Kala Pathar(paraphenylene Diamine) Poisoning: An Emerging Threat In Southern Punjab. J Coll Physicians Surg Pakistan. 2018 Jan 1;28(1):44-7. 10.29271/jcpsp.2018.01.44

17. Elgamel A, Ahmed N. Complications and management of hair dye poisoning in Khartoum. Sudan Med Monit. 2013;8(3):146. 10.4103/1858-5000.132603

18. Omer Sultan M, Inam Khan M, Ali R, et al. Paraphenylenediamine (Kala Pathar) Poisoning at the National Poison Control Center in Karachi: A Prospective Study. Cureus. 2020;12(5):e8352. 10.7759/cureus.8352

19. Sakuntala P, Musa Khan P, Sudarsi B, Manohar S, Siddeswari R, Swaroop K. Clinical Profile and Complications of Hair Dye Poisoning. Int J Sci Res Publ. 2014;5(6). http://www.ijsrp.org/research-paper-0615/ijsrp-p4211.pdf

20. Khan N, Khan H, Khan N, Ahmad I, Shah F, Rahman AU MI. Clinical presentation and outcome of patients with paraphenylenediamine (kala-pathar) poisoning. Gomal J Med Sci. 2015;(14):3-6. http://www.gjms.com.pk/ojs24/index.php/gjms/article/view/1350/759 
21. Chrispal A, Begum A, Ramya I, Zachariah A. Hair dye poisoning - an emerging problem in the tropics: an experience from a tertiary care hospital in South India. Trop Doct. 2010 Apr 19;40(2):100-3. 10.1258/td.2010.090367

22. Suliman SM, Fadlalla M, Nasr M el M, Beliela MH, Fesseha S, Babiker M, et al. Poisoning with hair-dye containing paraphenylene diamine: ten years experience. Saudi J Kidney Dis Transpl. 6(3):286-9. http://www.sjkdt.org/text.asp?1995/6/3/286/40663

23. Saleh Khaskheli M, Shaikh S, Meraj M, Raza H, Aslam I. Paraphenylenediamine poisoning: Clinical features, complications and outcome in a tertiary care institute. Vol. 22, Anaesthesia, Pain and Intensive Care. 2018; 343-347 p. https://www.researchgate.net/publication/329591062_Paraphenylenediamine_poisoning _Clinical_features_complications_and_outcome_in_a_tertiary_care_institute

24. Beshir L, Kaballo B, Young D. Attempted suicide by ingestion of hair dye containing pphenylenediamine: a case report. Ann Clin Biochem Int J Lab Med. 2017 Jul 8;54(4):507-10. $\underline{10.1177 / 0004563216685117}$

25. Jain DK, Mittal A. Hair Dye Poisoning $\square$ : Case Report and Review of Literature. 2018. DOI: 10.29252/arakmu.10.6.51

26. Kallel H, Chelly H, Dammak H, Bahloul M, Ksibi H, Hamida C Ben, et al. Clinical manifestations of systemic paraphenylene diamine intoxication. J Nephrol. 18(3):308-11. Academia.edu

27. Kondle R, Pathapati RM, Saginela SK, Malliboina S, Makineedi VP. Clinical Profile and Outcomes of Hair Dye Poisoning in a Teaching Hospital in Nellore. ISRN Emerg Med. 2012;2012:1-5. https://doi.org/10.5402/2012/624253 